\title{
Hydrological Assessment of Trace Metal Components from Some Lentic Fresh Water Aquifers, South West Coast of India
}

\author{
Meera D ${ }^{1}$, Sherly P. Anand ${ }^{2}$, Sanal Kumar M. G. ${ }^{3}$ \\ ${ }^{1}$ Research Scholar, P.G. and research department of Zoology, S.N. College, Kollam- 691001, Kerala, South India \\ ${ }^{2}$ Principal, S.N. College for Women, Kollam-691001, Kerala, South India \\ ${ }^{3}$ Assistant professor, Postgraduate and Research Department of Zoology, N.S.S. College, Pandalam, Pathanamthitta - 689 501, Kerala, \\ South India
}

\begin{abstract}
The current study was carried out for examining the heavy metal pollution profile of seven urban ponds in Chavara industrial area, south west coast of India. The study was conducted seasonally for a period of one year from January 2014 to December 2014. Results obtained from AAS analysis showed that toxic heavy metals such as copper (Cu), Manganese(Mn), zinc(Zn), Iron(Fe), lead(Pb), Cadmium(Cd), Nickel(Ni), Cobalt (Co), and Chromium $(\mathrm{Cr})$ in the water samples were found to be higher than drinking water standards prescribed by WHO, BIS and FAO. This study is an attempt to compare the hydrological assessment of heavy metals in water of different ponds due to pollution from near industry-KMML, situates in Chavara, Kollam, India.
\end{abstract}

Keywords: industrial area, toxic heavy metals, heavy metal pollution, hydrological assessment.

\section{Introduction}

Water, the universal solvent is the most vital component for all forms of life on earth. Over $71 \%$ of earth crust is covered with water. Of these only $0.3 \%$ is available as fresh water in rivers, streams, lakes and ponds. Safe and pure drinking water is the right of humans and all life forms on earth. Nevertheless industrialization and urbanization always leads to deterioration of water quality profile of most of the aquatic ecosystems. Fresh water bodies such as rivers, lakes, ponds etc are always under threat due to unscientific waste disposal strategies. Of these ponds have great ecological importance as they control flood, soil erosion and act as a good buffering system [1]. Ponds are lentic shallow water bodies, have an immense water retention capacity to maintain a balanced water column of an ecosystem. At local level ponds contribute more to biodiversity by supporting more unique and scare species [2].Hence monitoring and conservation of aquatic ecosystem are gaining importance due to its uniqueness. Urban watersheds are getting polluted mainly due to dumping of both solid and liquid untreated industrial and domestic wastes. This long term discharge results in percolating these pollutants in to ground water leads to destroying the natural habitats of both aquatic and terrestrial ecosystems. Kerala Minerals and Metals Ltd (KMML) is one of the leading profits making public sector, sited at coastal belt, Chavara, Kollam District in Kerala. KMML produces hazardous sludge as waste product during the production of titanium dioxide. This sludge contain large amount of heavy metals [3]. The improper management of waste products results in percolating them in to the surrounding water column which leads to degradation of complete ecosystem. These heavy metal contaminants will destroy the neighboring aquatic and terrestrial ecosystem completely and permanently.

\section{Materials and Methods}

Water samples were collected from seven different fresh water ponds from the study area, during pre monsoon, monsoon, post monsoon and summer from January 2014 to December 2014. Residents were not using the pond water in this area for any house hold purposes but utilize the water for fishing, cattle raring, and duck rising. Seven sampling stations (S1 to S7) were preferred for this study based on the requirement of this investigation. For analysing the trace metals contents of water from the elected stations, water samples were collected in clean polyethylene, white two litre cans. After proper labelling, the samples were brought to the laboratory for further analysis using AAS.

\subsection{Sample examination.}

Water Samples were subjected to atomic absorption spectrometer for being analyzed for metals like $\mathrm{Cu}, \mathrm{Mn}, \mathrm{Zn}$, $\mathrm{Fe}, \mathrm{Pb}, \mathrm{Cr}, \mathrm{Cd}, \mathrm{Ni}$, Co. Instrument was operated according to manufacturer's stipulation.

\section{Results and Discussion}

The data of trace metal components from seven selected fresh ponds were recorded during pre monsoon, monsoon, post monsoon and summer from January 2014 to December 2014 are presented below. Standard limits for drinking water prescribed by BIS, WHO and FAO was also given in Table 1.

Copper $(\mathbf{C u})$ : The common sources of copper pollution in aquatic ecosystems were mainly from industrial sources, domestic wastes, metal plating or mineral leaching [4]. Copper concentration ranged between $1.45 \mathrm{mg} / 1$ to $9.46 \mathrm{mg} / 1$ 


\section{International Journal of Science and Research (IJSR) \\ ISSN (Online): 2319-7064}

Index Copernicus Value (2013): 6.14 | Impact Factor (2014): 5.611

in different water samples, Seasonal data for copper in different stations are represented in Table 2. Highest concentration of copper was obtained in post monsoon from S5 $(9.46 \mathrm{mg} / \mathrm{L})$. Station average showed that lowest value was noticed from S7 $(3.99 \mathrm{mg} / \mathrm{L})$. Similarly, high copper value was reported by Sahib et al., 2009 from Ibb City, Yemen [5]. The analysis of variance (ANOVA) of copper showed that there is no significant variation between stations at $(\mathrm{P}<0.05)$, but showed that the season wise variation of copper is significant at $5 \%$ level. According to BIS and WHO desirable limit of $\mathrm{Cu}$ in drinking water is $0.05 \mathrm{mg} / \mathrm{L}$ and $1 \mathrm{mg} / \mathrm{L}$ respectively. From the present study it was clear that copper values of selected water samples were beyond the range prescribed by WHO, BIS and FAO values. According to Jayasree et al., [3] AAS analysis of KMML sludge contain $26.80 \mathrm{ppm}$ of $\mathrm{Cu}$. This much concentration of copper when accumulated in large quantity for long term without proper waste management system leads to severe pollution problem. Seasonal data showed that in all stations high concentration of copper was observed in post monsoon. Generally in post monsoon metal concentration will be less due to dilution of rain water. Irrespective of the diluting effect, in post monsoon highest copper concentration is a clear indication of pollution due to industrial effluents. Lowest copper content was observed in monsoon season, this may be due to dilution of rain water. Excess Copper accumulation results in various bodily disorders like hypertension, kidney dysfunctions, and various nervous disorders [6].

Manganese (Mn): Manganese is an essential element used by plants and animals for their proper growth and maintenance. In aquatic ecosystems manganese compounds gets attached to circulating particles or will settled in sediments [7]. Throughout the study a significant difference in concentration of manganese in all seasons was observed. Highest concentration was observed in post monsoon followed by summer and pre monsoon. Lowest mean value for manganese was reported in station two $(3.12 \mathrm{mg} / \mathrm{L})$. Mean value of manganese ranged from $1.52 \mathrm{mg} / \mathrm{L}$ to 9.15 $\mathrm{mg} / \mathrm{L}$ in $\mathrm{S} 7$ were shown in Table 3. According to BIS and WHO desirable limit of $\mathrm{Mn}$ in drinking water is $0.1 \mathrm{mg} / \mathrm{L}$. The values obtained for $\mathrm{Mn}$ in different stations were found to higher than Standard limits and guidelines for drinking water prescribed by BIS, WHO and FAO. The analysis of variance (ANOVA) of Manganese revealed a significant variation between the seasons at 5\% level but Station wise variation was found to have no such significant variation at $(\mathrm{P}<0.05)$. Jayasree et al., in 2009 analyses Mn concentration from KMML sludge and reported $1246.00 \mathrm{ppm}$ of $\mathrm{Mn}$ from it. [3]. Low Manganese concentration in monsoon may be due to high rain water influx. A very high concentrations of manganese observed in all stations in post monsoon season is a clear representation of pollution from anthropogenic sources like KMML effluent on that area. Even though Manganese is an essential micronutrient, its excess accumulation in humans results in neuronal disorders, bone diseases in babies, rheumatoid arthritis and diabetes [8], [9]. In mammals, manganese exposure on embryonic stage leads to foetal-toxicity and decreased postnatal growth [7], [10].

Zinc (Zn): Zinc is a significant trace metal, has chief role in maintaining proper physiological and metabolic process in most of the living organism. Nevertheless its high concentration results in toxicity. Industrial effluents, liquid manure, fertilizers and pesticides are the chief pollution sources of zinc in aquatic ecosystem. [11]. Zinc has an important role in protein synthesis. Since Zinc has restricted mobility its concentration is low in natural surface waters [12]. Decomposition of Zinc is difficult so will remain in the ecosystem for long periods. Hence become toxic to all aquatic organisms in its sub lethal concentration [13], [14]. Concentration of Zinc in water samples varied between $1.53 \mathrm{mg} / \mathrm{L}$ to $9.16 \mathrm{mg} / \mathrm{L}$ (Table 4). According to Jayasree $e t$ al., AAS analysis of KMML sludge contains $1854.00 \mathrm{ppm}$ of $\mathrm{Zn}$. [3]. Highest mean concentration was observed in post monsoon season. During post monsoon season high zinc content may be explained by the impact of waste water from industrial unit of KMML. In monsoon season the value of zinc was under permissible limit according to WHO and BIS standards $(5 \mathrm{mg} / \mathrm{L})$. In pre monsoon also all station except in S7 were under permissible limit according to WHO standards. In rainy season, dilution of metal concentration results in lowering the amount. The analysis of variance (ANOVA) showed that the variations between seasons were found significant at $5 \%$ level. But station wise variation was not found to be significant at $5 \%$ in the study period.

Iron (Fe): Industrial by products and domestic discharges contributes the main source of Iron pollution in water bodies. When present in high concentration results in colour changes in that water system. In the present study the mean value of iron varied from $1.66 \pm 0.01 \mathrm{mg} / \mathrm{L}$ (S6) to $9.73 \pm 0.19 \mathrm{mg} / \mathrm{L}$ (S1). AAS analysis of KMML sludge contains 151559.00 ppm of $\mathrm{Fe}$ [3]. Highest mean values were noticed in post monsoon seasons followed by pre monsoon and summer. From Table 5 it is clear that S7 shows highest Iron concentration when compared to other stations. According to FAO $5 \mathrm{mg} / \mathrm{L}$ is the desirable limit of Iron in drinking water. The analysis of variance (ANOVA) showed significant variation between seasons and between stations at $5 \%$ level.

Buffering actions of organic compounds or calcium salts make water less toxic even if the water contain iron in the above desirable limit [16],[17]. Even in post monsoon season high mean concentration of iron can be observed in all stations. This may be the result of intrusion of industrial effluent in to that area. Iron plays an important role in proper functioning of a human body. But when present in excess quantity will leads to high blood pressure, drowsiness, rapid blood clotting and increase in heart beat [15].

Lead (Pb): Metal plating, battery cells, dyes and pigments, chemical fertilizers, gasoline additives are the main Lead pollution sources in an aquatic ecosystem[8], [9]. In the present study mean concentration of lead values varies between $1.55 \mathrm{mg} / \mathrm{L}$ to $9.43 \mathrm{mg} / \mathrm{L}$ were shown in Table 6 . When compared to other stations, station wise mean concentration was highest for S2. According to WHO and BIS $0.05 \mathrm{mg} / \mathrm{L}$ is the desirable limit of $\mathrm{Pb}$ in drinking water. From the present study it is clear that lead concentration was above the permissible limit prescribed by WHO, BIS and FAO. From the studies conducted by Jayasree et al., in 2009 KMML sludge contains $101.40 \mathrm{ppm}$ of $\mathrm{Pb}$ [3]. From the mean values it is clear that highest mean value was obtained

\section{Volume 4 Issue 10, October 2015}




\section{International Journal of Science and Research (IJSR) \\ ISSN (Online): 2319-7064}

Index Copernicus Value (2013): 6.14 | Impact Factor (2014): 5.611

in Post monsoon followed by summer and pre monsoon. This seasonal behavior in heavy metal concentration can be explained by impact of industrial effluent on that area is high during wet season. The analysis of variance showed significant variation between seasons $(\mathrm{P}<0.05)$ and between stations $(\mathrm{P}<0.05)$. Lead is a toxic and dangerous heavy metal can cause serious health problems when enter inside the human body. Lead toxicity in humans can cause kidney dysfunction, damage to central nervous system and cardio vascular system and also cause infertility. Hemoglobin synthesis can be altered by lead toxicity [18].

Chromium (Cr): Chromium compounds are usually insoluble in water and occur in different oxidation states such as trivalent and hexavalent state. Chromium (III) oxide and chromium (III) hydroxide are the water soluble forms of Chromium compounds yet identified in nature [19]. In fresh water dissolved Chromium concentration ranged from 0$112 \mathrm{ppb}$ [20]. In present study mean value of Chromium varied between $0.94 \mathrm{mg} / \mathrm{L}$ to $9.73 \mathrm{mg} / \mathrm{L}$ was shown in Table 7. The observed value is higher than prescribed limit of BIS and WHO $(0.05 \mathrm{mg} / \mathrm{L})$. According to Jayasree et al., AAS analysis of KMML sludge contains 595.24 ppm of Cr. [3]. Higher concentrations of Chromium was observed in all station is a clear indication of industrial pollution in this area. In post monsoon season all station shows high mean values. Lowest mean values were reported from monsoon season in all stations. The analysis of variance (ANOVA) showed that the variation between station and seasons were significant at $5 \%$ level Electro plating, metal finishing, laundry chemicals, leather, road run off etc are the major sources of Chromium pollution. Chromium compounds play an important role in paint and dye industries as pigments and mordant. In humans, Chromium toxicity causes dermatitis, irritation with ulcers and other skin problems. In humans long term exposure of hexavalent chromium causes lung cancer, severe respiratory problems [20]..

Cadmium (Cd): Compare to other heavy metals, cadmium and its compounds have high toxicity and are water soluble, hence had higher chances for bioavailability and bioaccumulation. Cadmium is non biodegradable and will remain in nature for long period. In the present study Cadmium concentration varies from $1.41 \mathrm{mg} / \mathrm{L}$ to $8.61 \mathrm{mg} / \mathrm{L}$ (Table 8). Lowest mean concentration was reported from S2 and highest in station 4. According to Jayasree et al., AAS analysis of KMML sludge contains $3.20 \mathrm{ppm}$ of $\mathrm{Cd}$ [3]. Station mean shows that highest Cadmium concentration was reported in S4. Highest mean value for Cadmium was observed in post monsoon season followed by summer and pre monsoon. Lowest metal concentration was observed in monsoon season in all stations. The observed values of heavy metals in water samples were found to be higher than standard level of metal prescribed by WHO, BIS $(0.01 \mathrm{mg} / 1$ and $0.05 \mathrm{mg} / 1$ respectively) in drinking water. ANOVA showed highly significant variation between seasons and stations at $\mathrm{P}<0.05$. Chronic oral exposure of Cadmium in humans causes kidney stones, aminoaciduria, glucosuria, phosphaturia, osteomalacia, kidney dysfunction and osteoporosis. Continues high exposures can cause lung and prostate cancer. Major sources of Cadmium pollution were domestic waste water discharge, non-ferrous metal smelting and refining, and manufacturing of chemicals and metals [21], [22].

Nickel (Ni): nickel is a naturally occurring trace metal, soluble in water having no odor or taste. Common sources of Nickel pollution include industrial waste from nickel alloys or nickel compounds manufacturing plants, oil burning power plants, colour ceramic making plants, from batteries etc [23]. In humans nickel toxicity induce nausea, vomiting, abdominal pain, diarrhoea, breath problems etc [24]. Mean concentration of Nickel ranged from $1.23 \mathrm{mg} / \mathrm{L}$ to $9.84 \mathrm{mg} / \mathrm{L}$ was shown in Table 9. Highest nickel concentration was reported from station $7(6.32 \mathrm{mg} / \mathrm{L})$. According to Jayasree et al., AAS analysis of KMML sludge contains $112.30 \mathrm{ppm}$ of $\mathrm{Ni}$ [3]. This sludge due to improper management, accumulated in the factory premises may leach to the nearby surroundings leads to pollute the nearby ecosystem . Lowest mean concentration of Nickel was observed on monsoon season in all stations. This may be due to subsequent dilution of rain water. High concentration was observed in post monsoon seasons and this may be due to precipitation and discharge of high amount of industrial waste in to this water sheds. The analysis of variance (ANOVA) showed that there is significant variations occur between seasons at $5 \%$ level. But station wise variation was not significant at 5\% during the study period. The observed values of heavy metals in water samples were found to be higher than standard level of metal prescribed by FAO $(0.2 \mathrm{mg} / \mathrm{l})$. Nickel can combine with chlorine, sulfates, phosphates, oxygen, iron and manganese to form different hydroxide of Nickel [25].

Cobalt( Co): Cobalt is an important trace metal found in surface water, air, lechates of hazardous industrial effluents, sediments etc. Cobalt may reach the environment through anthropogenic activities like cobalt processing industries or mining ores, sewage sludge, combustion of fossil fuels etc. Cobalt is needed for maintaining proper health of a human body. It is an important component of Vitamin B12 .But over exposure of cobalt in humans result in lung diseases, heart problems, vomiting, reproductive toxicity etc [26] [27]. In the present study mean concentration ranged from $1.02 \mathrm{mg} / \mathrm{L}$ to $8.11 \mathrm{mg} / \mathrm{L}$.. From the observed mean it is clear that in post monsoon season highest metal concentration was observed in all station. This may be due to the effect of highly polluted water containing industrial effluent discharging in to this area. In this study minimum concentration was observed in monsoon season. This trend in monsoon could be of consequent dilution due to rain water. The observed mean concentrations of heavy metals were found to be higher than standard level of FAO $(0.05 \mathrm{mg} / \mathrm{L})$. The analysis of variance (ANOVA) showed high significant variations occur between seasons at $5 \%$ level. But there is no such significant variations between stations were observed at 5\% during the study period.

\section{Conclusion}

The present study clearly indicates that the pond water samples collected from Chavara Industrial area are not suitable any purposes relater to human consumption or house hold activities or other activities like animal raring or fish 


\section{International Journal of Science and Research (IJSR) \\ ISSN (Online): 2319-7064 \\ Index Copernicus Value (2013): 6.14 | Impact Factor (2014): 5.611}

farming and other domestication purposes. From the result of two-way ANOVA analysis of selected sites and samples showed that there was a very significant variation among different season for the concentration of copper $(\mathrm{Cu})$, Manganese(Mn), $\quad \operatorname{zinc}(\mathrm{Zn}), \quad \operatorname{Iron}(\mathrm{Fe}), \quad$ lead( $\mathrm{Pb})$, Cadmium(Cd), Nickel(Ni), Cobalt(Co) and Chromium(Cr) were observed from the water samples. Heavy metal concentration in these water samples are beyond the desirable limit of drinking water standards prescribed by BIS, WHO, FAO. This could be due to the discharge of industrial untreated waste and leaching of polluted waste water in to the study area. In the past three decades, huge amount of untreated contaminated sludge with heavy metal have been generated by KMML in Chavara area. Due to improper waste management system these waste materials cause contamination to the whole aquatic ecosystems in that area lead to high levels of heavy metals such as $\mathrm{Cu}, \mathrm{Mn}, \mathrm{Zn}, \mathrm{FE}$, $\mathrm{Pb}, \mathrm{Cd}, \mathrm{Ni}, \mathrm{Co}, \mathrm{Cr}$ accumulation. Hence, it is recommended that sustainable steps should be taken for proper waste disposal and secure waste management strategies is essential to evade any further contamination.

\section{Metals in Sludge with Concentration Limits}

Table 3: Heavy

\begin{tabular}{|c|c|c|}
\hline $\begin{array}{c}\text { Heavy } \\
\text { metals }\end{array}$ & $\begin{array}{c}\text { Concentration in } \\
\text { KMML sludge (ppm) }\end{array}$ & $\begin{array}{c}\text { Concentration limits (ppm) } \\
\text { KSPCB, Govt of Ind. }\end{array}$ \\
\hline $\mathrm{Cd}$ & 3.20 & 50 \\
\hline $\mathbf{C r}+\mathbf{6}$ & $\mathbf{5 9 5 . 2 4}$ & $\mathbf{5 0}$ \\
\hline $\mathrm{Cu}$ & 26.80 & 5000 \\
\hline $\mathbf{F e}$ & $\mathbf{1 5 1 5 5 9 . 0 0}$ & $\mathbf{5 0 0 0 0}$ \\
\hline $\mathrm{Mn}$ & 1246.00 & 50000 \\
\hline $\mathrm{Ni}$ & 112.30 & 5000 \\
\hline $\mathrm{Pb}$ & 101.40 & 5000 \\
\hline $\mathrm{Zn}$ & 1854.00 & 20000 \\
\hline
\end{tabular}

Source: Remediation of hazardous solid waste from titanium industries. Jayasree et al. [3]

Table 2: Seasonal variations of Copper (mg/L) in different stations in pond ecosystems during 2014

\begin{tabular}{|c|c|c|c|c|c|}
\hline \multirow{2}{*}{ Station } & Pr M & Mon & Po M & Sum & Mean \\
\cline { 2 - 5 } & $\mathrm{M} \pm \mathrm{SE}$ & $\mathrm{M} \pm \mathrm{SE}$ & $\mathrm{M} \pm \mathrm{SE}$ & $\mathrm{M} \pm \mathrm{SE}$ & $\mathrm{M} \pm \mathrm{SE}$ \\
\hline S1 & $6.79 \pm 0.08$ & $3.60 \pm 0.05$ & $8.92 \pm 0.31$ & $3.83 \pm 0.03$ & $5.78 \pm 0.66$ \\
\hline S2 & $4.73 \pm 0.09$ & $2.49 \pm 0.02$ & $6.53 \pm 0.44$ & $4.21 \pm 0.38$ & $4.49 \pm 0.45$ \\
\hline S3 & $3.72 \pm 0.12$ & $1.58 \pm 0.02$ & $8.36 \pm 0.38$ & $3.99 \pm 0.38$ & $4.42 \pm 0.75$ \\
\hline S4 & $4.65 \pm 0.06$ & $1.45 \pm 0.09$ & $6.81 \pm 0.64$ & $4.68 \pm 0.16$ & $4.40 \pm 0.59$ \\
\hline S5 & $3.77 \pm .005$ & $2.46 \pm 004$ & $9.46 \pm 0.40$ & $4.37 \pm 0.24$ & $5.02 \pm 0.80$ \\
\hline S6 & $4.73 \pm 0.04$ & $2.44 \pm 0.08$ & $7.23 \pm 0.30$ & $4.32 \pm 0.19$ & $4.68 \pm 0.51$ \\
\hline S7 & $2.41 \pm 0.18$ & $1.70 \pm 0.12$ & $7.43 \pm 0.23$ & $4.40 \pm 0.27$ & $3.99 \pm 0.67$ \\
\hline
\end{tabular}

Table 3: Seasonal variations of Copper (mg/L) in different stations in pond ecosystems during 2014

\begin{tabular}{|l|l|l|l|l|l|}
\hline Station & Pre monsoon & Monsoon & Post monsoon & Summer & Mean \\
\cline { 2 - 6 } & $\mathrm{M} \pm \mathrm{SE}$ & $\mathrm{M} \pm \mathrm{SE}$ & $\mathrm{M} \pm \mathrm{SE}$ & $\mathrm{M} \pm \mathrm{SE}$ & $\mathrm{M} \pm \mathrm{SE}$ \\
\hline S1 & $3.58 \pm 0.03$ & $2.59 \pm 0.13$ & $8.97 \pm 0.46$ & $5.38 \pm 0.41$ & $3.68 \pm 0.74$ \\
\hline S2 & $2.50 \pm 0.19$ & $1.53 \pm 0.04$ & $8.20 \pm 0.16$ & $5.66 \pm 0.18$ & $3.12 \pm 0.79$ \\
\hline S3 & $2.65 \pm 0.11$ & $1.57 \pm 0.12$ & $8.80 \pm 0.13$ & $5.99 \pm 0.30$ & $3.29 \pm 0.86$ \\
\hline S4 & $2.73 \pm 0.04$ & $1.52 \pm 0.05$ & $9.06 \pm 0.30$ & $5.88 \pm 0.25$ & $3.28 \pm 0.88$ \\
\hline S5 & $3.65 \pm 0.10$ & $2.66 \pm 0.09$ & $7.41 \pm 0.29$ & $6.01 \pm 0.15$ & $3.86 \pm 0.57$ \\
\hline S6 & $3.80 \pm 0.16$ & $2.44 \pm 0.09$ & $8.32 \pm 0.40$ & $4.89 \pm 0.31$ & $3.54 \pm 0.66$ \\
\hline S7 & $5.77 \pm 0.06$ & $3.25 \pm 0.22$ & $9.15 \pm 0.36$ & $5.07 \pm 0.34$ & $4.43 \pm 0.65$ \\
\hline
\end{tabular}

Table 4: Seasonal variations of Zinc ( $\mathrm{mg} / \mathrm{L})$ in different stations in pond ecosystems during 2014

\begin{tabular}{|c|c|c|c|c|c|}
\hline \multirow{2}{*}{ Station } & Pre monsoon & Monsoon & Post monsoon & Summer & Mean \\
\cline { 2 - 6 } & $\mathrm{M} \pm \mathrm{SE}$ & $\mathrm{M} \pm \mathrm{SE}$ & $\mathrm{M} \pm \mathrm{SE}$ & $\mathrm{M} \pm \mathrm{SE}$ & $\mathrm{M} \pm \mathrm{SE}$ \\
\hline S1 & $3.57 \pm 0.03$ & $2.59 \pm 0.13$ & $8.63 \pm 0.70$ & $5.38 \pm .041$ & $5.04 \pm 0.71$ \\
\hline S2 & $2.50 \pm 0.19$ & $1.53 \pm 0.04$ & $8.20 \pm 0.16$ & $5.66 \pm 0.18$ & $4.47 \pm 0.79$ \\
\hline S3 & $2.65 \pm 0.11$ & $1.57 \pm 0.12$ & $9.13 \pm 0.43$ & $5.99 \pm 0.30$ & $4.83 \pm 0.90$ \\
\hline S4 & $2.73 \pm 0.04$ & $1.53 \pm 0.05$ & $8.73 \pm 0.51$ & $5.88 \pm 0.25$ & $4.71 \pm 0.85$ \\
\hline S5 & $3.65 \pm 0.10$ & $2.67 \pm 0.09$ & $7.08 \pm 0.41$ & $6.02 \pm 0.15$ & $4.85 \pm 0.54$ \\
\hline S6 & $3.80 \pm 0.16$ & $2.44 \pm 0.09$ & $7.35 \pm 0.42$ & $4.89 \pm 0.31$ & $4.62 \pm 0.55$ \\
\hline S7 & $5.78 \pm 0.06$ & $3.25 \pm 0.22$ & $9.16 \pm 0.37$ & $5.07 \pm 0.34$ & $5.81 \pm 0.65$ \\
\hline
\end{tabular}




\section{International Journal of Science and Research (IJSR) \\ ISSN (Online): 2319-7064 \\ Index Copernicus Value (2013): 6.14 | Impact Factor (2014): 5.611}

Table 5: Seasonal variations of iron $(\mathrm{mg} / \mathrm{L})$ in different stations in pond ecosystems during 2014

\begin{tabular}{|c|c|c|c|c|c|}
\hline \multirow{2}{*}{ Station } & Pre monsoon & Monsoon & Post monsoon & Summer & Mean \\
\cline { 2 - 6 } & $\mathrm{M} \pm \mathrm{SE}$ & $\mathrm{M} \pm \mathrm{SE}$ & $\mathrm{M} \pm \mathrm{SE}$ & $\mathrm{M} \pm \mathrm{SE}$ & $\mathrm{M} \pm \mathrm{SE}$ \\
\hline S1 & $5.56 \pm 0.15$ & $2.76 \pm 0.06$ & $9.73 \pm 0.19$ & $4.63 \pm 0.02$ & $5.67 \pm 0.77$ \\
\hline S2 & $4.51 \pm 0.08$ & $2.46 \pm 0.07$ & $9.37 \pm 0.16$ & $4.26 \pm 0.20$ & $5.15 \pm 0.77$ \\
\hline S3 & $5.67 \pm 0.11$ & $2.41 \pm 0.05$ & $8.68 \pm 0.06$ & $4.17 \pm 0.26$ & $5.23 \pm 0.69$ \\
\hline S4 & $4.67 \pm 0.04$ & $2.65 \pm 0.08$ & $6.77 \pm 0.12$ & $4.17 \pm 0.15$ & $4.56 \pm 0.44$ \\
\hline S5 & $3.72 \pm 0.12$ & $2.53 \pm 0.05$ & $8.77 \pm 0.11$ & $3.66 \pm 0.05$ & $4.67 \pm 0.72$ \\
\hline S6 & $2.66 \pm 0.06$ & $1.66 \pm 0.01$ & $8.14 \pm 0.16$ & $2.99 \pm 0.28$ & $3.86 \pm 0.75$ \\
\hline S7 & $8.55 \pm 0.05$ & $5.55 \pm 0.11$ & $9.20 \pm 0.39$ & $3.37 \pm 0.35$ & $6.66 \pm 0.71$ \\
\hline
\end{tabular}

Table 6: Seasonal variations of lead $(\mathrm{mg} / \mathrm{L})$ in different stations in pond ecosystems during 2014

\begin{tabular}{|c|c|c|c|c|c|}
\hline \multirow{2}{*}{ Station } & Pre monsoon & Monsoon & Post monsoon & Summer & Mean \\
\cline { 2 - 6 } & $\mathrm{M} \pm \mathrm{SE}$ & $\mathrm{M} \pm \mathrm{SE}$ & $\mathrm{M} \pm \mathrm{SE}$ & $\mathrm{M} \pm \mathrm{SE}$ & $\mathrm{M} \pm \mathrm{SE}$ \\
\hline S1 & $3.87 \pm 0.05$ & $2.59 \pm 0.12$ & $6.94 \pm 0.48$ & $6.63 \pm 0.13$ & $5.00 \pm 0.56$ \\
\hline S2 & $7.84 \pm 0.08$ & $4.54 \pm 0.08$ & $8.03 \pm 0.26$ & $9.43 \pm 0.25$ & $7.46 \pm 0.54$ \\
\hline S3 & $3.63 \pm 0.06$ & $1.55 \pm 0.06$ & $8.52 \pm 0.28$ & $5.46 \pm 0.28$ & $4.79 \pm 0.77$ \\
\hline S4 & $3.80 \pm 0.12$ & $2.59 \pm 0.12$ & $8.92 \pm 0.50$ & $6.37 \pm 0.26$ & $5.15 \pm 0.77$ \\
\hline S5 & $3.73 \pm 0.08$ & $1.56 \pm 0.11$ & $8.77 \pm 0.15$ & $4.12 \pm 0.49$ & $4.54 \pm 0.79$ \\
\hline S6 & $3.76 \pm 0.06$ & $1.71 \pm 0.06$ & $8.84 \pm 0.16$ & $4.40 \pm 0.26$ & $4.67 \pm 0.78$ \\
\hline S7 & $3.81 \pm 0.17$ & $2.36 \pm 0.09$ & $7.95 \pm 0.02$ & $4.78 \pm 0.19$ & $4.72 \pm 0.62$ \\
\hline
\end{tabular}

Table 7: Seasonal variations of chromium (mg/L) in different stations in pond ecosystems during 2014

\begin{tabular}{|c|c|c|c|c|c|}
\hline \multirow{2}{*}{ Station } & Pre monsoon & Monsoon & Post monsoon & Summer & Mean \\
\cline { 2 - 5 } & $\mathrm{M} \pm \mathrm{SE}$ & $\mathrm{M} \pm \mathrm{SE}$ & $\mathrm{M} \pm \mathrm{SE}$ & $\mathrm{M} \pm \mathrm{SE}$ & $\mathrm{M} \pm \mathrm{SE}$ \\
\hline S1 & $3.4 \pm 0.09$ & $2.37 \pm 0.04$ & $9.07 \pm 0.52$ & $3.13 \pm 0.42$ & $4.49 \pm 0.81$ \\
\hline S2 & $2.28 \pm 0.08$ & $1.17 \pm 0.06$ & $7.73 \pm 0.23$ & $2.52 \pm 0.72$ & $3.42 \pm 0.77$ \\
\hline S3 & $2.47 \pm 0.12$ & $0.94 \pm 0.02$ & $7.03 \pm 0.36$ & $2.67 \pm 0.23$ & $3.27 \pm 0.68$ \\
\hline S4 & $2.50 \pm 0.06$ & $1.51 \pm 0.16$ & $6.74 \pm 0.15$ & $2.19 \pm 0.51$ & $3.23 \pm 0.62$ \\
\hline S5 & $5.35 \pm 0.01$ & $2.53 \pm 0.03$ & $7.67 \pm 0.15$ & $2.96 \pm 0.39$ & $4.62 \pm 0.62$ \\
\hline S6 & $4.55 \pm 0.10$ & $2.54 \pm 0.08$ & $7.12 \pm 0.36$ & $3.55 \pm 0.10$ & $4.44 \pm 0.51$ \\
\hline S7 & $4.35 \pm 2.8 \times 10^{-03}$ & $2.63 \pm 0.10$ & $9.73 \pm 0.13$ & $3.10 \pm 0.40$ & $4.95 \pm 0.85$ \\
\hline
\end{tabular}

Table 8: Seasonal variations of cadmium $(\mathrm{mg} / \mathrm{L})$ in different stations in pond ecosystems during 2014

\begin{tabular}{|l|l|l|l|l|l|}
\hline Station & Pre monsoon & Monsoon & Post monsoon & Summer & Mean \\
\cline { 2 - 6 } & $\mathrm{M} \pm \mathrm{SE}$ & $\mathrm{M} \pm \mathrm{SE}$ & $\mathrm{M} \pm \mathrm{SE}$ & $\mathrm{M} \pm \mathrm{SE}$ & $\mathrm{M} \pm \mathrm{SE}$ \\
\hline S1 & $2.99 \pm 0.32$ & $1.49 \pm 0.06$ & $7.99 \pm 0.49$ & $3.13 \pm 0.67$ & $3.90 \pm 0.76$ \\
\hline S2 & $2.49 \pm 0.08$ & $1.41 \pm 0.13$ & $6.66 \pm 0.06$ & $3.64 \pm 0.93$ & $3.55 \pm 0.62$ \\
\hline S3 & $2.62 \pm 0.12$ & $1.68 \pm 0.09$ & $7.52 \pm 0.30$ & $3.44 \pm 0.29$ & $3.81 \pm 0.67$ \\
\hline S4 & $3.62 \pm 0.09$ & $2.43 \pm 0.07$ & $8.61 \pm 0.08$ & $3.81 \pm 0.62$ & $4.62 \pm 0.72$ \\
\hline S5 & $2.72 \pm 0.13$ & $1.53 \pm 0.06$ & $6.74 \pm 0.09$ & $4.31 \pm 0.28$ & $3.82 \pm 0.59$ \\
\hline S6 & $3.66 \pm 0.12$ & $2.50 \pm 0.08$ & $7.78 \pm 0.09$ & $4.03 \pm 0.52$ & $4.49 \pm 0.60$ \\
\hline S7 & $4.87 \pm 0.05$ & $2.76 \pm 0.15$ & $8.84 \pm 0.57$ & $3.99 \pm 0.45$ & $5.11 \pm 0.70$ \\
\hline
\end{tabular}

Table 9: Seasonal variations of Nickel $(\mathrm{mg} / \mathrm{L})$ in different stations in pond ecosystems during 2014

\begin{tabular}{|l|l|l|l|l|l|}
\hline Station & Pre monsoon & Monsoon & Post monsoon & Summer & Mean \\
\cline { 2 - 5 } & $\mathrm{M} \pm \mathrm{SE}$ & $\mathrm{M} \pm \mathrm{SE}$ & $\mathrm{M} \pm \mathrm{SE}$ & $\mathrm{M} \pm \mathrm{SE}$ & $\mathrm{M} \pm \mathrm{SE}$ \\
\hline S1 & $3.53 \pm 0.13$ & $2.53 \pm 0.07$ & $7.88 \pm 0.05$ & $7.58 \pm 0.15$ & $5.37 \pm 0.71$ \\
\hline S2 & $3.93 \pm 0.02$ & $1.80 \pm 0.08$ & $8.04 \pm 0.42$ & $5.99 \pm 0.33$ & $4.94 \pm 0.71$ \\
\hline S3 & $3.66 \pm 0.12$ & $2.47 \pm 0.10$ & $8.87 \pm 0.05$ & $6.44 \pm 0.28$ & $5.36 \pm 0.75$ \\
\hline S4 & $2.66 \pm 0.12$ & $1.23 \pm 0.13$ & $9.40 \pm 0.41$ & $4.18 \pm 0.35$ & $4.36 \pm 0.93$ \\
\hline S5 & $2.76 \pm 0.06$ & $1.45 \pm 0.11$ & $9.46 \pm 0.64$ & $8.51 \pm 2.28$ & $5.54 \pm 1.06$ \\
\hline S6 & $2.56 \pm 0.22$ & $1.44 \pm 0.06$ & $9.51 \pm 0.71$ & $6.76 \pm 0.13$ & $5.06 \pm 0.99$ \\
\hline S7 & $5.81 \pm 0.08$ & $2.44 \pm 0.11$ & $9.84 \pm 0.42$ & $7.2 \pm 0.38$ & $6.32 \pm 0.81$ \\
\hline
\end{tabular}

Table 10: Seasonal variations of Cobalt $(\mathrm{mg} / \mathrm{L})$ in different stations in pond ecosystems during 2014

\begin{tabular}{|c|c|c|c|c|c|}
\hline \multirow{2}{*}{ Station } & Pre monsoon & Monsoon & Post monsoon & Summer & Mean \\
\cline { 2 - 6 } & $\mathrm{M} \pm \mathrm{SE}$ & $\mathrm{M} \pm \mathrm{SE}$ & $\mathrm{M} \pm \mathrm{SE}$ & $\mathrm{M} \pm \mathrm{SE}$ & $\mathrm{M} \pm \mathrm{SE}$ \\
\hline S1 & $1.65 \pm .0 .12$ & $1.02 \pm 0.10$ & $7.59 \pm 0.12$ & $5.73 \pm 0.18$ & $4.00 \pm 0.83$ \\
\hline S2 & $2.73 \pm 0.12$ & $1.25 \pm 0.02$ & $8.11 \pm 0.17$ & $5.43 \pm 0.11$ & $4.37 \pm 0.79$ \\
\hline S3 & $3.4 \pm 0.07$ & $2.1 \pm 0.28$ & $7.55 \pm 0.33$ & $4.65 \pm 0.06$ & $4.43 \pm 0.61$ \\
\hline S4 & $4.45 \pm 0.26$ & $2.58 \pm 0.14$ & $7.99 \pm 0.25$ & $5.58 \pm 0.12$ & $5.15 \pm 0.59$ \\
\hline S5 & $3.72 \pm 0.13$ & $1.53 \pm 0.88$ & $7.69 \pm 0.06$ & $4.73 \pm 0.05$ & $4.42 \pm 0.66$ \\
\hline S6 & $3.62 \pm 0.08$ & $1.57 \pm 0.10$ & $7.88 \pm 0.05$ & $5.67 \pm 0.12$ & $4.68 \pm 0.70$ \\
\hline S7 & $2.72 \pm 0.13$ & $1.69 \pm 0.08$ & $6.19 \pm 0.64$ & $5.83 \pm 0.06$ & $4.10 \pm 0.60$ \\
\hline
\end{tabular}

Volume 4 Issue 10, October 2015

www.ijsr.net 


\section{International Journal of Science and Research (IJSR) \\ ISSN (Online): 2319-7064}

Index Copernicus Value (2013): 6.14 | Impact Factor (2014): 5.611

\section{References}

[1] Satyasiba Bedamatta, "Ecological and Institutional Understanding of Chilika Lagoon. In: Lakes and Coastal Wetlands - Conservation, Restoration and Management" International Conference on Conservation, Restoration, and Management of Lakes and Coastal Wetlands and Management of Lakes and Coastal Wetlands, pp. 358-381, 2007.

[2] P. Williams, M. Whitfield, J. Biggs, S. Bray, G. Fox, P. Nicolet, D. Sear. 2004. Comparative biodiversity of rivers, streams, ditches and ponds in an agricultural landscape in Southern England, Biological Conservation, 115 pp. 329341,2004

[3] P. K. Jayasree, Y. Sheela Evangeline, and K. J. Sudhir, "Remediation of hazardous solid waste from titanium industries. Indian geo technical society. Guntur, India," pp. 296- 300, 2009

[4] T. Byragi Reddy, Ch. Venkata Ramana, Ch. Bhaskar \& P. Jagadeesh chandrababu Assessment of heavy metal study on ground water in and around Kapuluppada MSW site, Visakhapatnam, AP., International Journal of Science and Nature, 3(2), pp. 468-471, 2012

[5] Yemen Esmail Al Sabahi, S. Abdul Rahim, W.Y. Wan Zuhairi, Fadhl Al Nozaily and Fares Alshaebi , American Journal of Environmental Sciences: The Characteristics of Leachate and Groundwater Pollution at Municipal Solid Waste Landfill of Ibb City, 5 (3), pp. 256-266, 2009

[6] A. K. Krishna, P. K. Govil, "Heavy metal contamination of Soil around Pali Industrial Area,Rajasthan, India," Environmental Geology, 47(1), pp. 38-44, 2004.

[7] Annalisa Pinsino, Valeria Matranga, Maria Carmela Roccheri, "Manganese: A New Emerging Contaminant in the Environment," http://www.cnr.it/istituti/Allegato_79909.pdf

[8] S. A. Abbasi, Naseema Abbasi, Soni Rajendra, "Heavy metals in the environment," Mittal publications, 1, pp. 314, 1998.

[9] Aboud S. Jumbe , N. Nandini, "Impact assessment of heavy metals pollution of Vartur lake, Bangalore," Journal of Applied and Natural Science 1(1) pp. 53-61, 2009

[10] M. T. Colomina, J. L.Domingo, J. M. Llobet, J. Corbella, "Effect of day of exposure On the developmental toxicity of manganese in mice," Veterinary \& Human Toxicology, 38(1), pp. 7-9, 1996.

[11] S. Srinivasa Gowd, Pradip K. Govil, "Distribution of heavy metals in surface water of Ranipet industrial area in Tamil Nadu, India," Environ Monit Assess, 136, pp. 197-207, 2008.

[12] Ruqia Nazir, Muslim Khan, Muhammad Masab, Hameed ur Rehman, Naveed ur Rauf, Surrya Shahab, Nosheen Ameer, Muhammad Sajed, Mohib Ullah, Muhammad Rafeeq, Zeenat Shaheen, “ Accumulation of Heavy Metals $(\mathrm{Ni}, \mathrm{Cu}, \mathrm{Cd}, \mathrm{Cr}, \mathrm{Pb}, \mathrm{Zn}, \mathrm{Fe})$ in the soil, water and plants and analysis of physico-chemical parameters of soil and water Collected from Tanda Dam Kohat," J. Pharm. Sci. \& Res., 7(3), pp. 89-97, 2015.

[13] Ibemenuga, Keziah Nwamaka, bioaccumulation and toxic effects of some heavy metals in freshwater fishes," Animal Research International, 10(3), pp. 1792 - 1798, 2013.

[14] C. I. Nsofor, E. B. C.Ufodike, S. O. ONUOHA, "The bioaccumulation of some heavy metals in some organs of two commercial fish; Clarias gariepinus (Burchell) and Chrysicthys nigrodigitatus (Lacepede) from River Niger,
Onitsha shelf, Anambra State, Nigeria. Journal Of Aquatic Sciences," 22(1), pp. 33 - 38, 2007

[15] Gautam Patil, Irfan Ahmad,"Heavy metals contamination assesment of Kanhargaon dam water near Chhindwara city, Acta Chim. Pharm. Indica, 1(1), pp. 7-9, 2011.

[16] P. S. Welch, "Limnological Methods," McGraw Hill Book Co., Inc. New York, pp. 538, 1952.

[17] Fawzia Adib Flowra, Jibon Kumar Ghosh, Md. Abu Sayed Jewel, Anannya Sen Tumpa, M. Afzal Hussain, "Analysis of heavy metal components in some urban ponds in Rajshahi, Bangladesh ," J. Life Earth Sci., 7 pp. 115-117, 2012.

[18] Rashmi Verma, Pratima Dwivedi, "Heavy metal water pollution- A case study," Recent Research in Science and Technology, 5(5), pp. 98-99, 2013.

[19] M. Pavan, G.Benarjee, "Studies on physico-chemical parameters and occurrence of heavy metals in an urban lake of Warangal district during different seasons," International journal of plant, animal, and environmental science, 5(3), 2015.

[20] L. E. Towill, Carole R. Shriner, John S. Drury, Anna S.Hammons, Jamesw, Holleman reviews of the environmental effects of pollutants: III, CHROMIUM, pp. $12-17,1978$.

[21] Cadmium in Drinking-water Background document for development of WHO Guidelines for Drinking-water Quality, 2011.

[22] Nordic Council of Ministers Cadmium Review, 2003 http://www.who.int/ifcs/documents/forums/forum5/nmr_ca dmium.

[23] U.S. department of health and human services, Public Health Service Agency for Toxic Substances and Disease Registry. http://www.atsdr.cdc.gov/toxfaqs/tfacts15.pdf

[24] F William Sunderman, Brian Dingel, Sidney M. Hopfer, Thomas swift "Acute Nickel Toxicity in Electroplating Workers who accidentally ingested a solution of nickel sulphate and nickel chloride," American journal of industrial medicine, 14 , pp. 257-266,1988

[25] D. Barałkiewicz, J. Siepak, "Chromium, Nickel and Cobalt in Environmental Samples and Existing Legal Norms," Polish Journal of Environmental Studies, 8(4), pp. 201-208, 1999.

[26] James H. Kim, Herman J. Gibb, Paul D. Howe, "Cobalt and inorganic cobalt compounds," WHO, Concise International Chemical Assessment Document 69, pp. 1-85, 2006.

[27] Heavy metals contaminations of soil and water at Agbogbloshie Scrap Market, Accraboadu Theophilus marfo May, 2014

\section{Author Profile}

Meera D received the B.Sc and M.Sc degrees in Zoology from M.G University, Kottayam, Kerala in 2007 and 2009, respectively. She is now with Kerala University as Research scholar in Dept of Zoology, SN College, Kollam. 